\title{
Public and Private Ownership in the Iranian Constitution: Principle 44, A Barrier for Development
}

\author{
Ahmad Torabi ${ }^{1}$ \\ ${ }^{1}$ Faculty member of Azad University branch North Tehran, Iran \\ Correspondence: Ahmad Torabi, Faculty member of Azad University branch North Tehran, Iran. E-mail: \\ ahmad.torabi06@gmail.com
}

Received: May 1, 2017

Accepted: July 1, $2017 \quad$ Online Published: August 30, 2017

doi:10.5539/jpl.v10n4p73

URL: https://doi.org/10.5539/jpl.v10n4p73

\begin{abstract}
The Iranian legislator has sought to protect public property and public ownership in the Iranian Constitution in accordance with Islamic principles, terms and procedures. ${ }^{1}$ There are a number of principles that have been directly applied to this purpose; however, one principle has had a very significant impact on government domination of the economy of Iran: principle 44 . This principle does not directly describe public property; rather, it aims to determine the areas that are under public ownership and are administered by the government. However, the principle has some contradictions and legal challenges in itself. In addition, the supplementary law that has been enacted to provide the areas for the enforcement of principle 44 fails to secure the aims of the legislator. Therefore, this paper analyses legal challenges of the principle, as well as its supplementary law, and gives suggestions to solve the challenges.

This paper is divided into four sections. The first section provides an analysis of the principle itself, and its relationship and consistency with other principles of the constitution. In the second section, the Law of Implementation of Principle 44 and the legal challenges that arise from it will be discussed. The third section focuses on the negative economic impacts of this law, as well as case studies of it. Lastly, the paper provides a summary of suggestions to amend this law.
\end{abstract}

\section{Introduction}

This paper focuses on the situation of public property and public ownership in the current Iranian Constitution, mainly on principle 44 . The author discusses the barriers and the legal challenges that arise, directly or indirectly, from implementation of this principle. There is also an extensive discussion of government control and the negative economic impacts of this law. The paper aims to explore the defects of this principle explicitly, and provides suggestions to improve it.

In certain sections of this article, translation of Iranian legal text has been provided by the author. Translation of legal texts (like any other texts) can be challenging, and potentially change the legal content of an article. In some cases, it is observed that the translations provided by the official websites of Iranian organizations are not accurate. However, the effort has been made by the author to ensure that the translation has been done accurately and responsibly.

\section{Analysis of the Principle 44, and Its Relationship with Other Principles of the Constitution}

A translation of principle 44 is provided in the following: ${ }^{2}$

"The economy of the Islamic Republic of Iran is based on three sectors: state, cooperative, and private, and is to be based on systematic and correct planning.

The State sector includes all large-scale and mother industries, foreign trade, major minerals, banking, insurance, power generation, dams, and large-scale irrigation networks, radio and television, post, telegraph and telephone, aviation, shipping, roads and railroads and the like; that would be [under] public ownership and [shall be]

\footnotetext{
${ }^{1}$ The Constitution of the Islamic Republic of Iran was adopted by a referendum on October 24, 1979, and came into force on December 3 of that year, replacing the Constitution of 1906. However, the new cconstitution was amended on July 28, 1989. The new cconstitution contains a preamble outlining a broad ideological vision for the nation as a whole, and 14 chapters and 177 principles.

${ }^{2}$ Islamic Republic of Iran Constitution, 1979 Principle 44
} 
administered by the State.

The cooperative sector includes cooperative companies and enterprises concerned with production and distribution, in urban and rural areas, established in accordance with Islamic criteria.

The private sector consists of those activities concerned with agriculture, animal husbandry, industry, trade, and services that supplement the economic activities of the State and cooperative sector.

Ownership in each of these three sectors is protected by the laws of the Islamic Republic, in so far as it is consistent with the other principles of this chapter, and does not go beyond the bounds of Islamic law, and contributes to the economic growth and progress of the country and does not harm the society.

The details of the regulations and scope and conditions each of these sectors, will be specified by law".

\subsection{Analysis of the Terminologies Applied in the Principle 44}

There are many terms and expressions in the above principle that could have a broad interpretation. Some of them are listed below:

The phrase "mother industries": This phrase is a direct translation from Farsi. It could be defined as denoting industries that are part of the economic infrastructure and are responsible for producing the tools of production (for example metal industries). Although the Iranian legislator refers to this concept repeatedly; the term itself is an economic one, and it does not have a legal definition. The use of this phrase in the legal context could result in broad interpretation of the law, which could cause ambiguity and uncertainty. It is also a definition that has the potential to adapt to changes in society.

The term "large-scale": This is another critical term that lacks any legal definition. Again, the term primarily belongs to the economic domain. At least from a legal perspective, one might expect that this definition must principally be clarified by laws that are enacted by the parliament (in Iran, through laws that are enacted by the Islamic Consultative Assembly). However, there is no law in the Iranian legal system that clearly defines so called "large-scale" industries. The lack of such laws in this regard results in ambiguity regarding the extent of public ownership. Such ambiguity arguably acts as a bar to the development of the private sector.

\subsection{Inconsistency with Principle 43}

According to the principle 44, public ownership is widely expanded and protected by the legislator, but it must be consistent with other principles of the constitution. However, principle 44 implies certain fundamental inconsistencies of principle 43 . Principle 43 provides: $^{3}$

ensuring conditions and opportunities of employment for everyone, with a view to attaining full employment; placing the means of work at the disposal of everyone who is able to work but lacks the means, in the form of cooperatives, through granting interest-free loans or recourse to any other legitimate means that neither results in the concentration or circulation of wealth in the hands of a few individuals or groups, nor turns the government into a major absolute employer. These steps must be taken with due regard for the requirements governing the general economic planning of the country at each stage of its growth" (Section 2);

the plan for the national economy, must be structured in such a manner that the form, content, and hours of work of every individual will allow him sufficient leisure and energy to engage, beyond his professional endeavour, in intellectual, political, and social activities leading to all-round development of his self, to take active part in leading the affairs of the country, improve his skills, and to make full use of his creativity. (Section 3)

Section 3 of this principle clearly acknowledges the right of every individual to participate in the development of the economy. Section 2 clearly prohibits the government from becoming "a major absolute employer". This expression leads to a simple fundamental inconsistency: it is almost impossible to implement both principles 43 and 44 , while the majority of leading productive economic activities (from dams and railroads to communication) are restricted to the State.

Furthermore, one might ask, if every individual has the right to participate in the development of the country, in what sense are the activities of the private sector reduced to a "supplementary role" as stated in principle 44?

\section{The Law of Implementation of General Policies of the Principle 44 (2004)}

Growing social and economic demands, some complex issues in principle 44, and the need for private sector investment eventually forced the Iranian authorities to implement extensive economic reforms through enactment of the so called "Law of Implementation of General Policies of Principle 44", which will be referred

${ }^{3}$ Ibid, principle 43, Section $2 \& 3$ 
to as the "Law of Implementation" for the sake of brevity. This section aims to provide a brief background and to explore the legal challenges which arise from this law.

\subsection{A Berief Background of the Law}

After mass nationalization in 1979 following the Islamic Revolution and the fall of 75 the Pahlavi regime, ${ }^{4}$ Iran faced several challenges. Perhaps the most significant challenge was the 8-year war with Iraq, a period during which no long-term economic plan could be implemented. However, confusion over economic policymaking and lawmaking was intensified during this period..$^{5}$

Iranian leadership reconsidered State control over the economy, and therefore the Law of the First Comprehensive Five-year Economic Plan was enacted in 1990. Based on this law, the private sector secured a greater share in some sectors of the economy of Iran. The private sector was allowed to participate in contracts with the government, and this was clearly intended to be a plan for privatization. ${ }^{6}$

According to the Law of the Second Five-year Economic Plan (for 1995-2000), the policy of economic stabilization, or Tasbite Eghtesadi, was enacted and the plan for liberalization, as well as privatization, was supported by the legislator. ${ }^{7}$ However, the strategy faced political, economic, and administrative barriers, as well as legal challenges regarding the extent of the role of the private sector in principle 44 of the constitution. Legal disputes arose between public organizations, which had been privatized according to the new policy, and their staff. ${ }^{8}$

The law of the Third Five-year Economic Plan was enacted for the years 2000-2005. For the first time there was a plan for participation of both the foreign and domestic private sectors in the privatization programs. The Iranian Privatization Organization (IPO) was established in June 2001 in order to coordinate such plans. ${ }^{9}$ Private banks and foreign banks were authorized to operate in Iran's free trade zones for the first time since 1979. This law accorded with the view expressed in principle 44 that public ownership must be reduced and the role of the private sector must be developed in all areas, including industries, trade and services.

The law of the Fourth Five-year Economic Plan was enacted by the Iranian Parliament in 2004. This law secured an even greater share for the private sector in the economy. The government was allowed to shift public ownership in most public corporations to the private sector through various methods, such as formation of leasing contracts with the private sector, sale of public corporations on hire purchase conditions, and so on. ${ }^{10}$ However, the law did not sufficiently predict the necessary legal issues for this purpose, such as the extent of public ownership in corporations that could be transferred to the private sector, or the role of the cooperative sector during privatization.

Finally, the Iranian Parliament amended the Fourth Five-year Economic Plan in order to ease the transfer of industries to the private sector. Since the Law of Implementation of General Policies of Principle 44 included a

\footnotetext{
${ }^{4}$ For example, according to Kaveh Ehsani, during this period public sector employment more than doubled after the revolution, from 1.7 million in 1976 to 3.5 million in 1986. According to one estimate, within three years of the revolution, one in six Iranians above the age of fifteen belonged to one state and revolutionary body or another. Kaveh Ehsani, Privatization of Public Goods in the Islamic Republic, Middle East Report 250 (2009): 26-33.

${ }^{5}$ There have been many legal challenges and disputes between the Iranian authorities regarding the extent of public ownership outlined in principle 44 of the constitution. For example, on May 10, 1980, legislation based on principle 44 was presented that gave the government exclusive control over foreign trade and importation/exportation. However, this legislation was so controversial that it took six years of legal debates between parliament, government, and the Guardian Council to resolve. Another example is the Land Reform Bill, which was implemented in early April 1980 and involved extensive land redistribution. However, this reform created an intense legal conflict. After protests by leading clergy, the bill was reformed dramatically. As Valibeigi notes, the ultimate significance of these debates, was determining the extent of public ownership in post-revolutionary Iran. Mehrdad Valibeigi, "Islamic Economics and Economic Policy Formation in Post-Revolutionary Iran: A Critique”, Journal of Economic Issues, 27(3) (Sep., 1993): 793-812

${ }^{6}$ The Law of the First Iran Comprehensive Five-year Economic Plan 1990, Articles 7, 9 and 11

7 The Law of the Second Iran Five-year Economic Plan 1994 Articles 10, 16, 17, 19, 20, 25, 51

${ }^{8}$ For example, after privatization of Telecommunication Organization in East Azarbayjan, the new general board decided to reduce the salaries of the staff. In addition, the company owed money to some of the former staff before being privatized, which the new general board refused the pay. This eventually led to a long legal battle which resulted in a decree from the Iranian Administrative High Court several years later (Heiaate Omomieye Divane Edalate Edari), Decree Number: 706, Case Number: 90/527, Date: 06/11/2014. According to this decree, all decisions regarding retirement of members of staff of Telecommunication Organization that were made before privatization are valid, and the new general board is obliged to pay the unpaid salaries, according to the decisions made before privatization.

${ }^{9}$ The Law of the Third Iran Five-year Economic Plan 2000, Collection of Laws 2001, Articles 4, 9, 11 and 15

${ }^{10}$ The Law of the Fourth Five-year Economic Plan 2004, Articles 6 \& 7
} 
broad transfer of public ownership to private sector, the Guardian Council ${ }^{11}$ considered it to be contrary to the aims of the constitution. Finally, the law was incorporated in a new form called "the Law of Implementation of General Policies of Principle 44". ${ }^{12}$ This new law was confirmed by the State Expediency Council. ${ }^{13}$

\subsection{Characterisics of the Law of Implementation}

The Act of Implementation of General Policies of Principle 44 is indeed the supplementary law for the principle, and aims to expand the role of the private sector in the economy. However, this Act touches on complex issues. According to this Act, economic activities are categorized as follows:

Group 1: All economic activities except the activities mentioned in groups 2 and 3. Government ownership over this group is prohibited ${ }^{14}$.

Group 2: Economic activities that are cited at the beginning of principle 44 of the constitution, except activities referred to in group 3 of this article. Government ownership over this group is permitted.

Group 3: Activities, institutions and companies such as mother industries, telecommunication networks, main networks, national Iranian Oil Company and the companies for the exploitation and production of crude oil and gas, Central Bank and some national banks, Central Insurance Company, and radio and TV fall under this group. Investment, ownership and management of activities and firms subject to group 3 of article 2 of this law will be restricted to the government and therefore cannot be privatized. ${ }^{15}$

The purchase of financial, technical, engineering and managerial services from non-government sectors engaged in activities of group 3 of article 2 of this law is subject to the condition that the government's hundred (100\%) percent ownership does not change, and is based on an executive order that shall be approved by the Council of Ministers. ${ }^{16}$

\subsection{Analysis of the Law of Implementaion of General Policies of the Princple 44}

This Law has not been successful in changing the policy of concentration of public ownership in the system. This has recently been confirmed by official reports from parliament. ${ }^{17}$ This section focuses on legal defects of this law:

The contents of the law are not in tune with the aim of the legislator. For example, if the aim of the law was to develop private ownership in economic activities in the main sectors of the economy, we see that the critical sectors of the economy, which are cited in group 2 of the law, have been excluded from private ownership. Naturally, private investors would become reluctant to invest in domestic and productive projects. The government remains the only partner with the right to control and administer most of the economy, and this clearly violates the purposes of privatization. ${ }^{18}$

\footnotetext{
${ }^{11}$ According to principles 91, 96, 98, and 99 of the constitution, the Guardian Council is formed to ensure that all the laws that are enacted by parliament are consistent with Islamic Sharia laws as well as the constitution. In addition, it settles any disputes in regards to interpretations of the constitution. The Guardian Council also supervises elections and referendums. It consists of twelve members, six of whom are appointed by the leader. The other six members are introduced by the head of the judiciary, and approved by parliament.

12 The Law of Implementation of Principle 44 of the Constitution 2004

${ }^{13}$ According to principle 112 of the constitution, the State Expediency Council is responsible for intervening whenever a dispute arises between the Guardian Council and parliament. Since the Guardian Council saw the Law of Implementation as contrary to principle 44, it was sent to the State Expediency Council for reconsideration, and ultimately reconfirmed. The members of the State Expediency Council are appointed by the Supreme Leader.

${ }^{14}$ What we have here is a residue or residuary clause. The style of drafting is perhaps somewhat unusual when compared to that encountered more commonly in Europe where the residuary clause is found at the end of the relevant legislation.

${ }^{15}$ The Law of Implementation of General Policies of Principle 44, articles 2 \& 3

${ }^{16}$ Ibid, Note 1 Section (c), article 3

${ }^{17}$ Some reports recently issued by the Islamic Consultative Assembly Research Centre clearly state that decreasing the role of public ownership for industries and mines, which was intended to be carried out by the government according to the Law of Implementation of General Policies of Principle 44, has not been successful. Four major enterprises that were assessed include Golgohar Mining \& Industrials Company, Chadormalu Mining and Industrial Company, National Iranian Copper, Mobarakeh Steel Company (MSC), Khozestan Steel Company and Iranian Aluminium Company. The report concludes that less that 10 percent of the shares were sold through the stock exchange. In fact, the majority of the transfers were between government sectors and semi-government institutions. Only a very small percentage of such transfers/sales were conducted on a competitive basis. In other words, this clearly violated the very purpose of privatization. Islamic Consultative Assembly Research Center, Study of the Extent of Success of Privatization of Mines and Mine Industries, Subject Code: 310, Number: 13485,August 2011

${ }^{18}$ This reluctance has resulted in inflation in the public budget. In other words, the expenditures of the government have not been reduced as a result of the enforcement of this law. A report issued by the Center for Strategic Research on February 2012 confirms this fact, and shows that the budget bill 2011 is inconsistent with the Law of General Principles of Principles 44. According to this report, the inconsistency in the
} 
The presence of ambiguity and uncertainty in the law acts as a barrier for privatization. No legal definition of the "private sector" is provided by this law. For example, there may be some corporations in which the government owns $49 \%$ percent of shares. Should these corporations be considered private or public? There may also be several corporations in which the government is a member of the board of managers, or one of the government officials is the general manager of the corporation. Is such a corporation private or public?

It seems logical to describe the private sector first, then to define its specifications and conditions to distinguish it from other sectors, and, finally, to set out the rights for this sector. Indeed, in order to ascertain what are the aims of the law; we must describe the private sector in its precise meaning. The existence of the private sector, by definition, requires independence in administration and economic decision making. Therefore, we may conclude that the private sector must have decisive ownership (greater than 50\%) (provided one also assumes the absence of some form of "golden" or controlling share with special and overriding management powers). In addition, its founding statute must guarantee independence of administration. Furthermore the founding statute must be protected from government intervention.

The Act does not provide a legal definition for the term "non-government public institutions". According to the said Act, the government is obliged to cede government shares to "non-government public institutions". However a question may arise. What is the nature of those institutions and how are they created?

There are several definitions of the term "non-government public institution" in other laws that cause ambiguity and uncertainty. For example, some "non-government public institutions" have been deemed to be government institutions by other laws. They have usually been created by law, and provide government services to third parties or services to the government. Most of such institutions use government financial aids, or even receive funds through an annual budget. For example, Bonyade Mostazafan and Janbazan Foundation (BMJ), ${ }^{19}$ the Iranian Red Crescent Society, the Iranian Olympic Committee, and Iranian Social Security are some of the institutions that receive funds through an annual budget, and have been considered as non-government institutions in the related laws. In the parlance of the Scottish constitutional set-up, these can be compared to QUANGOs - quasi-autonomous non-government organizations.

On the other hand, there are some other laws that have precisely excluded "non-government public institutions" from government organizations. For example, the law of the management of civil services has precisely provided that "non-government public institutions" are excluded from the laws that relate to government institutions. ${ }^{20}$

Therefore, the nature of such institutions is controversial and is not determined in the Iranian legal system. This has caused a weak institutional environment in the economy, and has led to destructive competition while reducing economic performance below its potential level.

However, whatever view one takes on this matter, "non-government public institutions" may not be considered as institutions of the private sector, to be eligible for ownership of public properties subject to the said law.

\section{Legal Disputes and Criticism Regarding the Law of Implementation}

The issue of "non-government public institutions" has been given various different names, such as "quasi-government institutions" or "semi-governmental sector", in Farsi legal texts. We now need to look at this phenomenon a little more closely.

The Law of Implementation has created the new economic phenomenon of "quasi-government institutions". ${ }^{21}$ These institutions seem independent from the government, and provide public services such as public transportation or holding and managements of factories, refineries and transportation. They usually enjoy operational and political independence. However, they are administered by the government and their members may be appointed by the government.

The issue has been illustrated in some privatization cases in which non-government institutions have been described as the "semi-governmental sector". The challenges arise during the transfer of State assets to a

budget bills has even grown since the implementation of the said law (Center for Strategic Research, Report on the Evaluation of the Consistence 2011 Budget Bill with General Policies of Principle 44, Number 142, Code report: 0-4-2-90-64, February 2012, page 6).

${ }^{19}$ According to Ali Saeidi, "This is a powerful organization in the economy and most of its corporations are exempted from taxes and many legal restrictions and assessments. In fact, this foundation is neither private nor state-owned." For details see, Ali A Saeidi, Iranian Studies 37:3 (Sep 2004): 485

${ }^{20}$ The Law of the Management of Civil Services 2006, Article 117

${ }^{21}$ The term has been used in Farsi legal discourse. The term indicates that there are some institutions that do not belong to the government but which receive financial services from the government in the annual budgets. 
"semi-governmental sector". 22

The accountability of this "semi-government sector" could be criticized, because essentially such organizations could act to protect the government from legal and political liability. For example, this type of transfer of assets could be used to transfer ownership of polluted land to the semi-governmental entity to avoid liability. Such institutions provide an example of contradiction and confusion, because it is not clear whether such institutions belong to the public or private domain. Forums in the public domain are supervised by the parliament and numerous other organizations; however, semi-government institutions have no legal obligation to disclose their policies, budget, etc. ${ }^{23}$ It seems that the legislator has to clarify decisively whether such institutions belong to the public or private domain to improve transparency. ${ }^{24}$ If such institutions are deemed to be public, they must be obligated to disclose their accounts to the public, and if they are deemed to be private, their access to public resources and budget must be restricted.

\subsection{An Analysis of Public Auditing Law ${ }^{25}$}

Public Auditing Law refers to definitions of government enterprises as well as non-government public institutions. The following is a translation of articles 4 and 5 of this law:

Article 4- A government enterprise is an organizational unit that is established as a forum according to the law, or nationalized based on law, or confiscated upon a proper court decree, and is known as a government enterprise, and more than 50 percent of its shares must belong to the government. Any commercial enterprise that is established through the investment of government enterprises shall be deemed a government enterprise, as long as 50 per cent of its shares belong to government enterprises.

Article 5- From the view of this law, non-government foundations and institutions are specific organization units that are established in order to conduct duties and public services by the permission of law. ${ }^{26}$

However, there are ambiguities within this law:

1) Regarding Article 4, the law does not predict the possibility of the government enterprise (GE) having an overriding managerial power within another commercial enterprise. In other words, a GE might have administrative and managerial power, with even less than 50 percent of the shares (e.g. a golden share). However, the law will regard such an enterprise as private, and therefore free from the need for auditing.

2) Article 5 has provided a definition of non-government institutions (NGI). However, there is no mention of the possibility of investment of an NGI in other commercial enterprises. In other words, it is possible that a NGI could invest in or establish another commercial enterprise using public resources, which is free from auditing or supervision, as long as the government allows it.

In is interesting to note that the above legal observations have a reflection in the reality of the Iranian economy. According to a report recently issued by the Consultative Assembly Research Centre, a large percentage of recently 'privatized' enterprises have been transformed into NGI's. In other words, public resources have been spent to purchase government enterprises. The report also indicates that the administrations of such enterprises are still influenced by the government. ${ }^{27}$

\footnotetext{
${ }^{22}$ For example, in September 27, 2009, 51 percent of shares of Telecommunication Company of Iran (TCI) were sold to Etemad Mobin Consortium in just 30 minutes. This was the largest ever floatation on the Tehran Stock Exchange, with $\$ 7.9$ billion being transferred. The consortium includes three companies, Mobin Electronics Development Company, Shahryar Mehestan, and Tose'e Etemad Investments, all affiliated with the IRGC (Islamic Revolutionary Guard Corps). The consortium is described as a quasi-governmental entity. During the TCI flotation, other contenders were disqualified on security grounds or lack of sufficient finance. This could be described as a policy against the main aims of privatization. Official website of the Iran Privatization Organization, "Third Section of the Report on Principle 44" (1 May 2010), <http://www.ipo.ir/index.aspx?siteid=1\&pageid= 167\&newsview=4805>, accessed 4/08/2014.

${ }^{23}$ Some commentators believe that this has resulted in the emergence of a grey area, between the public and private domain. For example, Nazib Ayubi noted that it is common to witness "private businesses cream off public resources and public officials 'parachute' on private companies." Nazib Ayubi, Political Correlates of Privatization Programs in the Middle East, Arab Studies Quarterly, 14 (1992): 39-56.

${ }^{24}$ This point has been noted in a recent study of the Islamic Consultative Assembly, titled "Comprehensive Study of Principle 44". M Nazar Abadi and O Atayi, Comprehensive Study of Principle 44 and Comparison between Government Legal Bill and Special Commission of Principle 44's Approvals, Islamic Consultative Assembly Research Center Press, Code Number 220, August 2007

${ }^{25}$ This law, which was approved in 1987, is the main tool in the hand of the Supreme Audit Court to supervise whether the income of the government is spent according to the annual budget. The law has 140 articles, and includes definitions regarding government enterprises and public institutions. Principles 54 and 55 of the Constitution of the Islamic Republic of Iran define the objectives and responsibilities of the Supreme Audit Court of Iran, and discuss the significance of the SAC in establishing proper management.

${ }^{26}$ Law of Public Auditing, 1987, articles 4 and 5

${ }^{27}$ See Islamic Consultative Assembly, no 16
} 
Although the report has noted the economic effect of the Law of Implementation, it does not criticize the underlying causes, which are principle 44 as well as the Public Auditing Law.

\subsection{Legal Disputes That Which Arise from the Law of Implementation}

There have been many legal disputes caused by principle 44 of the constitution and the Law of Implementation. This section aims to explore some cases in this area.

1) In Supreme Audit Court ${ }^{28}$ v High Council of Insurance ${ }^{29}$ (2014), the General Board of the Administrative Supreme Cour ${ }^{30}$ held that the permission issued by High Council of Insurance for insurance companies to determine their fees independently is void. The plaintiff argued that the right of determination of insurance fees falls only to the High Council of Insurance, and this right cannot be passed to insurance companies. In other words, the Insurance companies had no right to determine the insurance fees independently of the High Council of Insurance. The High Council of Insurance (the defendant), argued in response that such approvals were based on article 1, section 11 of the Law of Implementation, which has forbidden any type of determination of fees that results in disruption of competition in the market. However, this argument was not accepted. The General Board of the Administrative Supreme Court discussed that the Law of Implementation has only determined some general policies as the aims of the law, rather than any special rights for insurance companies to determine the insurance fees independently. In addition, according to section 7 of group 3 of article 2 of the Law of Implementation, the activities of the Central Insurance have been explicitly excluded from privatization activities. $^{31}$

The above decree dramatically illustrates the confusion in the Law of Implementation. On the one hand, the Supreme Insurance Company believes that its subordinate companies have the right to determine insurance fees independently; on the other, the Supreme Audit Court sees this permission as contravening the law, and ultimately the interpretation of the General Board of the Administrative Supreme Court resulted in voiding the permission. The decree can also illustrate another conflict in the Law of Implementation between article 1 section 11, and section 7 of group 3 of article 2 . According to article 1 , the aim of this law is to prevent the disruption of competition; while, based on article 2, only the High Council of Insurance can determine the prices and fees of insurance. In other words, article 2 provides the High Council of Insurance with a monopoly, while article 1, section 11, emphasises competition between insurances.

2) In L. Mosaiyan Jabar, A. Sayeban Kheyrabadi and M. Kayabi v. Ministry of Oil (2012), ${ }^{32}$ the General Board of the Administrative Supreme Court held that the approval of the cabinet was void. The cabinet approval in 2003 held that the staff of subordinate companies of the Ministry of Oil who were laid off due to the enforcement of the Law of Implementation should be administrated by the new organizations' rules and regulations. The plaintiffs, who were the staff of one of the subordinate companies, complained about cabinet approval and requested its cancellation. They argued that they had an employment contract with the Ministry of Oil and according to the principle of privity of the law of contract, which is mentioned in the Iranian Civil Code, ${ }^{33}$ only parties to the contract should be able to enforce their rights. Here, the cabinet was not the party of the contract, but rather the third party, and therefore had no right to cancel the employment contract between the Ministry of Oil and the staff. The plaintiffs also put forward another argument that every contract needs the mutual consent of both parties. ${ }^{34}$ They argued that in this case, there was no consent between the plaintiffs and subordinate

\footnotetext{
${ }^{28}$ The Supreme Audit Court of Iran is accountable to parliament. Principles 54 and 55 of Iran's constitution define the objectives and responsibilities of the Supreme Audit Court of Iran and reveal the significance of the SAC in establishing proper management.

${ }^{29}$ The Supreme Council of Insurance is an organization within Central Insurance of Iran. According to the first article of their law of establishment: "For the purpose of regulating, expanding, and guiding insurance operations in Iran and for guidance of the insurance companies, and the protection of the Insured and their beneficiaries as well as to ensure government supervision of such operations an organization named Bimeh Markazi Iran (Central Insurance of Iran) is hereby established in the form of a joint stock company".

${ }^{30}$ The General Board of the Administrative Supreme Court is the highest administrative court in the Iranian judicial system. Its members include high ranking judges, appointed by the head of the judiciary. It has the right to void approvals of the cabinet, statues, executive orders or decisions issued by other organizations.

${ }^{31}$ General Board of Administrative Supreme Court, Case Number: 90/166, Decree number: 485, date: 21/10/2013 (Divane Edalate Edari 2013)

${ }^{32}$ General Board of Administrative Supreme Court, Case Number: 88/498/869, Decree number: 265-266, date: 07/30/2012 (Divane Edalate Edari 2013)

${ }^{33}$ Iran Civil Code 1928, article 231 states: "Undertakings or contracts are only binding on the two parties concerned or their legal substitutes".

${ }^{34}$ This principle is also mentioned in the Iran Civil Code, which states: For the validity of a contract the following conditions are essential: I - The intention and mutual consent of both parties to the contract. Ibid, article 190
} 
organizations of the Ministry of Oil. Therefore, there was no employment contract on which the new organizations could execute new regulations over them.

The above decree illustrates another defect within the Law of Implementation. This law has given the cabinet an exclusive right to determine how the ownership of institutions should be transferred and administered. However, the law does not anticipate the challenges or the losses for the staff that may arise due to this transfer. For example, it does not mention how the staff who were laid off should be compensated. In other words, the government responsibility in regards to any losses has been completely neglected.

\section{Summary and Conclusion}

Principle 44 has fundamental inconsistencies within itself and with other parts of the constitution, including principle 43. The use of undefined terms or terms that belong to the economic domain add to the ambiguity. Principle 44 clearly provides the government with the possibility to dominate and control the economy, while principle 43 prohibits the government from being "a major absolute employer".

The Law of Implementation of General Policies of the Principle 44 was designed to secure a greater share of the economy for the private sector, however, as the reports suggest, this law was not successful. The contents of the Act are not in tune with the aim of the legislator. In fact, principle 44 provides extensive government domination. From the legal perspective, the law cannot breach the constitution. Therefore, the government still dominates the leading and productive sectors of the economy, such as telecommunication networks. The Law of Implementation has not only failed to clarify ambiguous terms, but in fact introduced new concepts to economy that need to be defined themselves. Arguably, the most significant impact of this law was the emergence of the phenomenon of "non-government institutions" in the economy of Iran. Such institutions have an advantage in accessing public resources. Some of them even receive an annual budget. However, they benefit from the process of privatization, as if they were part of the "true private sector", while they are not under any legal obligation to disclose their accounts to any supervising organization. The lack of efficient laws in regards to auditing such organizations, in particular the defects of the Public Auditing Law, leads to a waste of public resources as well as violating the principles of competition, which ultimately results in reluctance on the part of the private sector to invest in the economy.

It is necessary to amend principle 44 in order to solve the issues arising from it and the Law of Implementation. There are fundamental inconsistencies within the structure and the spirit of the said laws, which prevent any further amendment. In other words, no law can breach a principle of the constitution; therefore, no amendment can be enacted without any contradiction.

The author suggests that principle 44 be rewritten, containing the following characteristics:

1) Avoid using undefined economic terminology in place of legal definitions. In other words, if an economic concept is discussed, a legal definition must be provided. For example, if the phrase "private sector" is used, a legal definition of the private sector must be provided that secures its administrative independence.

2) There should not be any inconsistency with other principles of the constitution, including principle 43 .

3) It seems that the Iranian legislator has attempted to secure a greater share for the private sector in recent years. If this is the intention, the content of the principle must reflect it, and therefore the ownership of private enterprises must be acknowledged over leading sectors of the economy. It is worth noting that discussion about the advantages or disadvantages of privatization falls entirely within the scope of economic considerations, and is not the subject of this article. However, when the legislator decides to act on such discussion, it is automatically incorporated in the legal domain, and at that point, there should not be any inconsistencies with the constitution. 